\title{
Sosyal Bilgiler Öğretmen Adaylarının Yaratıcı Dramanın Bir Öğretim Yöntemi Olarak Kullanımına İlişkin Görüşleri ${ }^{1}$
}

\author{
Feyzullah EZER² ve Ülkü ULUKAYA-ÖTELEȘ³
}

$\ddot{O} z$

Bu çalışma, Sosyal bilgiler öğretmen adaylarının Sosyal bilgiler dersinde yaratıcı dramanın bir öğretim yöntemi olarak kullanımına ilişkin görüşlerinin ortaya konulmasını amaçlamaktadır. Araştırmanın çalışma grubunu, 2016-2017 eğitimöğretim y1lında Doğu Anadolu bölgesinde bir devlet üniversitesinin, Eğitim Fakültesi Türkçe ve Sosyal Bilimler Eğitimi Bölümü, Sosyal Bilgiler Öğretmenliği Anabilim Dalı'nda eğitim gören 4. sınıf 42 öğretmen adayı oluşturmaktadır. Veri toplama aracı olarak görüşme tekniğinin kullanıldığı bu araştırmada, verilerinin çözümlenmesinde içerik analizi ve betimsel analiz tekniği kullanılmıştır. Araştırmada veri toplama aracı olarak araştırmacı tarafından geliştirilen yarı yapılandırılmış görüşme formu kullanılmıştır. Araştırma neticesinde elde edilen genel bulgular öğretmen adaylarının yaratıcı drama kavramına ilişkin tanımlarının farklılaştığını göstermektedir. Öğretmen adaylarının çoğunluğu yaratıcı dramayı doğaçlamaya dayalı gösteri yöntemi olarak tanımlamıştır. Araştırmadan elde edilen diğer bulgular öğretmen adaylarının Sosyal bilgiler dersinde yaratıcı drama yönteminin kullanılması yönünde büyük oranda olumlu bir tutuma sahip olduğunu ve yaratıcı drama yöntemi konusunda aldıkları eğitimi yeterli görmediğini de ortaya koymaktadır. Aynı zamanda öğretmen adayları yaratıcı drama yöntemini meslek hayatlarında uygularken çeşitli sorunlarla karşılaşabileceğini belirtmişlerdir. Son olarak bulgular öğretmen adaylarının büyük çoğunluğunun meslek hayatlarına başladıklarında bu yöntemi kullanmak istediklerini göstermektedir.

Anahtar Kelimeler: Sosyal bilgiler, Drama yöntemi, Öğretmen adayları

\section{Social Studies Teacher Candidates' Views on the Usage of Creative Drama as a Method of Teaching}

\section{Abstract}

The purpose of this study is to explore the candidates' views for teachers of social sciences on the usage of creative drama as a method of teaching in social sciences. The research team consists of 42 teacher candidates of 4 th grade students studying at the Faculty of Turkish Language and Social Sciences of Eastern Anatolia State University in 2016-2017 academic year. The semi-structured questionnaire which was made up by the researcher and content analysis methods were used as data collecting tool in this research. The general results obtained as a result of the study shows that teachers candidates' concept of creative drama are different. Most of teacher candidates identified creative drama as an improvisation-based demonstration method. According to other results of the study teachers have a great positive attitude towards using creative drama in the social sciences. At the same time, teacher candidates stated that they may come across with various problems when applying the method of creative drama in their professional life. In conclusion the results show that most of teacher candidates want to use this method when they begin their professional life.

Key Words: Social studies, Drama method, Teacher candidates

\section{Atıf İçin / Please Cite As:}

Ezer, F. ve Ulukaya-Öteleş, Ü. (2020). Sosyal bilgiler öğretmen adaylarının yaratıcı dramanın bir öğretim yöntemi olarak kullanımına ilişkin görüşleri. Manas Sosyal Araştırmalar Dergisi, 9(2), $709-718$.

Geliş Tarihi / Received Date: 20.01.2019

Kabul Tarihi / Accepted Date: 23.10.2019

\footnotetext{
${ }^{1}$ Bu çalışmanın özet metni VI Uluslararası Sosyal Bilgiler Eğitimi Sempozyumunda sunulmuştur.

${ }^{2}$ Dr. Öğr Üyesi - Fırat Üniversitesi Eğitim Fakültesi, Türkiye, fezer@firat. edu.tr ORCID: 0000-0002-5862- 8541

${ }^{3}$ Dr. Öğr Üyesi - Muş Alparslan Üniversitesi Eğitim Fakültesi, Türkiye, u.ulukaya@alparslan.edu.tr ORCID: 0000-0002-5780-2034
} 


\section{Giriş}

Sosyal bilgiler dersi eğitim programı incelediğimizde yapılandırmacı anlayış doğrultusunda şekillendiği görülebilir (Bilgili, 2006, s.7). Yapılandırmacı yaklaşım, öğrenme-öğretme sürecinin merkezine öğrenen bireyleri yerleştiren böylece bireylerin tüm öğrenme-öğretme süreci boyunca aktif bir katıllımcı olabilmesini destekleyen modern bir yaklaşımdır (Chen, 2003, s. 21). Bu yaklaşımda öğretmenden eğitim-öğretim sürecine rehberlik etmesi, bireyin bilgiyi etkili bir şekilde kazanmasına ve hayatta uygulamasına basamak oluşturması beklenilmektedir. Yapılandırmacı yaklaşımı benimseyen öğretmen, öğrenme ortamlarındaki mutlak otorite değil, öğrenen bireylerin yeni bilgileri keşfedip öğrenmesinde ve anlamlandırmasında onları destekleyen, hata ve eksiklerini fark ederek gidermelerinde rehberlik eden kişi olarak görülmektedir (Şimşek, 2009, s.126).

Sosyal Bilgiler dersi bilişsel yönü ağır basan bir derstir. Bu derste sadece geleneksel öğretim yöntem ve tekniklerinin kullanılması bireyde yaşantı oluşturmaya engel teșkil etmektedir. Oysaki yapılandırmacı eğitimin temelinde bireyin öğrenmede aktif rol alması anlayışı hâkimdir (Ömeroğlu, Ersoy, Şahin, Kandır ve Turla, 2003, s. 21-22). Yeni Sosyal Bilgiler Programı yapılandırmacı yaklaşıma göre hazırlanarak öğrencinin bilgiyi oluşturduğu buluş, araştırma-inceleme stratejilerinin uygulanması, buna göre yöntem ve tekniklerin kullanılmasını savunmaktadır (Koçoğlu, 2017, s. 2). Bu yöntemlerden biri olan drama yöntemi, yaparak, yaşayarak öğrenme süreci açısından en etkili yöntemlerden biridir (Aykaç ve Çetinkaya, 2013, s. $302)$.

Dramanın birçok çeşit ve tanımı mevcuttur. Bunlar içinde yaratıcı drama, eğitici drama, psikodrama ve sosyodrama çeşitleri en fazla kullanılan drama çeşitleridir (Karadağ ve Çalıskan, 2008, s. 50). Drama kelimesinin kökü olan dran kelimesi ile aynı anlama gelen devinim sözcüğü zaman içinde durum değiştirmek anlamına gelmektedir. Ciddi dinsel törenler için kullanılan dromenan kelimesinin kullanılması bağlamında dran sözcügü bir şeyi yapmaya çalışmak anlamında da kullanılır. Bu bilgiler sşığında drama, bir ya da birçok kişinin birbirleriyle, tabiatla ya da başka varlıklarla etkileşime girerek onların bütün yaşam durumlarını geniş ölçüde içeren faaliyetler şeklinde tanımlanabilir (Adıgüzel, 2014, s.1). Yaratıcı drama ise, "Bir grupla grup üyelerinin yaşantılarından yola çıkarak, bir amacın, düşüncenin, doğaçlama, rol oynama gibi tekniklerden yararlanarak canlandırılmasıdır” (Adıgüzel, 2015, s. 56).

San'a göre ise yaratıcı drama; doğaçlama, rol oynama vb. tiyatro ya da drama tekniklerinden yararlanılarak, bir grup çalışması içinde, bireylerin bir yaşantıyı, bir olayı, bir fikri, bir eğitim ünitesini, kimi zaman da soyut bir kavramı ya da davranışı, eski bilişsel örüntülerin yeniden düzenlenmesi yoluyla ve gözlem, deneyim, yaşantıların gözden geçirildiği "oyunsu” süreçlerde anlamlandırılması, canlandırmasıdır (San, 1996, s. 149). Diğer bir tanıma göre ise; bir öğretim yöntemi, sanat eğitimi alanı ve bir disiplin olarak bireylerin 2000'li yıllarda kendini rahatça ifade edebilen, yaratıcı, grup çalışmalarına açık kişiler olmalarını sağlayacak bir yaklaşımdır (Üstündağ, 1996, s.19).

Tekerek "Yaratıcı Dramanın Özgürlüğ̈̈, Alı̧kanlıkların Kalıpları ve Bir Uygulama Örneği” adlı çalışmasında yaratıcı dramayı bireyin özgüven kazanmasında ve kendini var etmesinde işlevsel olan, somuttan soyuta ya da soyuttan somuta ilerleyen süreçte yaratıcılık, düş gücü, ortak hareket etme, organizasyon, empati, iç disiplin, özgürlük ve sayg1 gibi insani değerleri geliştirerek önemli katkılar sağlayan bir yaşantı olarak tanımlamıştır (Tanrıseven ve Aykaç, 2013, s.332).

Yaratıcı drama çalışmalarını sadece öğrenciye bir takım bilgileri kavratmaya çalışan bir yaklaşım olarak düşünmek eksik olacaktır. Buna ilaveten yaratıcı drama öğrencinin toplumsallaşmasına, kendisine olan güveninin artmasına yardımcı olabilmektedir. (Gönen ve Dalkılıç, 2000, s. 75).Yaratıcı drama çalışmaları örgün eğitimin her basamağında, yaygin eğitimde de dersler içinde ve bir öğretim yöntemi olarak yer almaktadır (San, 1996). Yaratıcı drama, bireyin dil kullanım alanlarını ve niteliğini de genişletebilmektedir. Kendi içinde bir dil biçimi olan yaratıcı drama, öğrencilere, kendi ve başkalarına karşı eleştirel yaklaşma olanağ1 sunar (Aytaç ve Çetinkaya, 2013, s. 675). Soyut kavramların yoğunlukta olduğu Sosyal bilgiler dersinde drama yönteminin kullanılması başarıyı artırmada önemli bir role sahiptir (Kara ve Çam, 2007, s. 152). Bununla birlikte yaratıcı drama, çocuklara erişemeyecekleri durumları yaşama ve öğrenme imkânı tanımaktadır (Çalışkan ve Karadağ, 2005). Yaratıcı drama çalışmaları sırasında öğrenci duygu ve düşüncelerini rahatça ifade edebilmekte ve duygularının ayrımına varabilme yetisi kazanabilmektedir (Dirim, 1998, s.35).

Öğrenciler açısından bu denli öneme sahip olan bu derse yönelik öğretmen adaylarının görüşleri çok önemlidir. Yaratıcı drama yönteminin eğitim-öğretim sürecinde kullanma kararını öğretmen vermektedir. 
Öğretmen adaylarının bu yönteme ilişkin olumsuz tutumları varsa sebebi tespit edilmeli gerekli çalışmalar yapılmalıdır. Bu bağlamda araştırmanın amacı yaratıcı drama yönteminin etkililiğine ilişkin öğretmen adaylarının görüşlerinin alınmasıdır.

\section{Araştırmanın Amacı}

Bu araştırmanın genel amacı, Sosyal Bilgiler Eğitimi Ana Bilim Dalı’nda öğrenim gören 4. sınıf öğretmen adaylarının yaratıcı drama yöntemine ilişkin görüşlerinin değerlendirilmesidir. Bu genel amaç doğrultusunda aşağıdaki sorulara cevap aranmıştır:

1. Sosyal Bilgiler Öğretmenliği Bölümünde öğrenim gören öğretmen adaylarının yaratıcı drama yönteminin ne olduğu hakkındaki görüşleri nelerdir?

2. Sosyal Bilgiler Öğretmenliği Bölümünde öğrenim gören öğretmen adaylarının yaratıcı dramanın Sosyal bilgiler dersinde kullanılmasına ilişkin görüşleri nelerdir?

3. Sosyal Bilgiler Öğretmenliği Bölümünde öğrenim gören öğretmen adaylarının yaratıcı drama yöntemine yönelik yeterlilik alg1ları hakkındaki görüşleri nelerdir?

4. Sosyal Bilgiler Öğretmenliği Bölümünde öğrenim gören öğretmen adaylarının drama yöntemini uygulamada karşılaşabilecekleri problemlere yönelik görüşleri nelerdir?

5. Sosyal Bilgiler Öğretmenliği Bölümünde öğrenim gören öğretmen adaylarının drama yönteminin Sosyal bilgiler dersinde uygulanmasına yönelik görüşleri nelerdir?

\section{Yöntem}

$\mathrm{Bu}$ araştırmada, nitel araştırma yöntemlerinden görüşme tekniği kullanılmıştır. Nitel araştırmada kapsamında yer alan görüşme farklı sınıflara ayrılmaktadır. Bunlar; yapılandırılmış, yarı-yapılandırılmış ve yapılandırılmamış görüşmedir. İlgili araştırmanın verileri görüşme türlerinden yarı yapılandırılmış görüşsme tekniği ile toplanmıştır. Yapılandırılmış ve yapılandırılmamış görüşmeler arasında yer alan görüşme yarı yapılandırllmış görüşmedir (Karasar, 2007, s. 168).

\section{Çalışma Grubu}

İlgili araştırmanın çalışma grubu belirlenirken amaçlı örnekleme yöntemleri içerinde yer alan ölçüt örnekleme yönteminden yararlanılmıstır. Ölçüt örnekleme yönteminde ilgili problemin özelliklerini yansıtan durum, kişi olay ya da nesnelerden yararlanılmaktadır (Büyüköztürk, Çakmak, Akgün, Karadeniz ve Demirel, 2009). Araştırmada, uygulamanın yaplacağı bireylerin seçiminde araştırmacı tarafindan belirlenen temel ölçüt, Sosyal bilgiler öğretmenliği bölümünde öğrenim görüp drama dersini almış öğrencilerin seçilmesidir. Çünkü bu araştırmada Sosyal Bilgiler öğretmen adaylarının yaratıcı dramaya ilişskin görüşlerinin belirlenmesi amaçlanmaktadır. Bu bağlamda da araştırmanın çalışma grubu 2016-2017 eğitim-öğretim yllında Doğu Anadolu bölgesinde bir devlet üniversitesinin, Eğitim Fakültesi Türkçe ve Sosyal Bilimler Eğitimi Bölümü, Sosyal Bilgiler Öğretmenliği Anabilim Dalı’nda eğitim gören 4. sinıf 42 öğretmen adayı oluşturmaktadır. Her bir öğretmen adayı 1'den 42 kadar G.1 (Görüşmeci 1), G.5 (Görüşmeci 5) gibi kodlar kullanılarak tanımlanmıştır.

Tablo 1. Arasttrmaya Katılan Öğretmen Adaylarmm Cinsiyete Göre Dağgllmı

\begin{tabular}{lcc}
\hline & $\mathbf{N}$ & $\mathbf{\%}$ \\
\hline Kiz & 18 & 42.8 \\
Erkek & 24 & 57.1 \\
Toplam & 42 & 100 \\
\hline
\end{tabular}

\section{Veri Toplama Araçları}

Veri toplama aracı olarak araştırmacı tarafindan oluşturulan yarı yapılandırılmış görüşme formu kullanılmıştır. Formu oluşturan soruların anlaşır olması, yönlendirici ve yanıltıcı olmamasına dikkat edilmiştir. Sosyal Bilgiler öğretmen adaylarının yaratıcı drama yönteminin etkililiğine ilişkin görüşlerinin belirlenmesi amacıyla hazırlanan görüşme formunda 5 soru maddesi yer almaktadır. Sorular hazırlanırken ilgili konuya ilişkin literatür taranmı̧ ve konuyla ilgili önemli hususlar belirlenmiştir. Hazırlanan görüşme formunun amaca ne derece hizmet ettiği, anlaşllırlığ1 ve uygulanabilirliğini kontrol etmek amacıyla, 2alan uzmanı ve 2 ölçme değerlendirme uzmanın görüşlerinden yararlanılmıstır. Oluşturulan soruların 
güvenirliliğini sağlamak maksadıyla Miles ve Huberman (1994) tarafından önerilen güvenirlik formülü kullanılmıştır. Bu bağlamda öğretmen adaylarının verdiği cevaplar, araştırmacı tarafından kodlanmış, bununla birlikte kodlanan tüm veriler okunarak, o kodun temelde ne ifade ettiği tespit edilmeye çalışılmıştır. Oluşturulan kodlar, kategorilere ayrılıp, araştırmanın temaları belirlenmiştir. Çalışmanın devamında araştırmacı ve uzmanın kodlama sisteminde yer alan ortak ve farklı görüşler tespit edilmiştir. "Görüş farklıllğının görüldüğü kodlarda, araştırmacının kodu kabul edilmiştir. Bu çalışma sürecinin devamında görüş ayrılığının ve görüş birliğinin sağlandığı kodlar belirlenmiştir, Miles ve Huberman'nın (1994) P (Uzlaşma Yüzdesi) = Na (Görüş Birliği) / Na (Görüş Birliği) + Nd (Görüş Ayrllı̆̆ı) x 100 formülünden yararlanılarak kodlayıcılar arası güvenirlik hesaplanmış ve güvenirlik $\mathrm{P}=\% 83$ bulunmuştur.

\section{Veri Toplama Süreci}

Araştırma verilerine öğretmen adaylarının görüşme formunda yer alan sorulara verdikleri yanıtla doğrultunda ulaşılmıştır. Adaylarla sessiz bir ortamda ortalama olarak 15- $20 \mathrm{dk}$ süren görüşmeler gerçekleştirilmiştir. Öğretmen adaylarına görüşme sürecini başlatmadan önce araştırmanın amac1 ve ulaşılan verilerin hangi amaçla toplandığ1 ve nerelerde kullanılacağ1 hususunda bilgi verilmiştir. Katılımcılardan görüşmelerin kayıt edilmesi konusunda izin alınmıştır.

\section{Verilerin Analizi}

Araştırma kapsamında elde veriler betimsel analiz ve içerik analiz yöntemiyle incelenmiştir. Betimsel analiz; ulaşılan verilerin, önceden oluşturulan temalar çerçevesinde yorumlandığı ve görüşmecilerin belirli bir konuya yönelik duygu ve düşüncelerini yansitan ifadelerden doğrudan yararlanıldığı analiz tekniğidir (Yıldırım ve Şimşek, 2005). Çalışma doğrultusunda görüşme formundan elde edilen veriler incelenmiş ve bu kapsamda da kodlamalar oluşturulmuştur. Kodlamalar esas alınarak temalar (kategoriler) ortaya çıkarılarak betimsel ve içerik analizleri yapılmıştır. Güvenirlik hesaplaması için, Miles ve Huberman (1994) tarafından önerilen güvenirlik formülünde [Güvenirlik = Görüş Birliği / (Görüş Birliği + Görüş Ayrıllğı)] yararlanılmıştır. Araştırmacıların \%85 ve üstünde ortak düşünceye sahip olduğu noktalar; yaratıcı drama etkinliklerine dair tanımlamaları, yaratıcı drama yönteminin Sosyal bilgiler dersinde kullanılıp/kullanılmaması yönündeki fikirleri, yaratıcı drama konusunda yeterlilik düzeyleri, yaratıc1 dramanın sınıf ortamında uygulanmasında karşılaşabilecekleri problemler ve son olarak göreve başladıklarında yaratıcı dramayı Sosyal bilgiler dersinde uygulayıp/uygulayamayacaklarına ilişkin bulguları gösteren tablo hazırlanmıştır.

Tablo 2. Miles ve Huberman Güvenirlik. Hesaplaması Doğrultusunda Sorulan Güvenirlik Puanlar

\begin{tabular}{lc}
\hline Soru & P \\
\hline 1 & 85 \\
2 & 90 \\
3 & 85 \\
4 & 80 \\
5 & 80 \\
\hline
\end{tabular}

\section{Bulgular}

Bu bölümde, öğretmen adaylarının Sosyal bilgiler dersi öğretiminde yaratıcı drama yönteminin etkililiğine ilişkin görüşleri genel başlıklar halinde temalara ve verilen ortak cevaplar doğrultusunda alt temalara dönüştürüldükten sonra frekans değerleri bulunmuş ve tablolar halinde sunulmuştur.

\section{Yaratıcı drama yönteminin tanımı}

Araştırmaya katılan 42 öğretmen adayının yaratıcı drama yöntemine yönelik tanımlarının farklılaştığı görülmüştür. Öğretmen adaylarının verdiği cevaplar gruplanıp alt temalar oluşturularak tablo halinde sunulmuştur. 
Tablo 3. Siẓce Yaratıc Drama Yöntemi Nedir? Sorusuna Yönelik Öğretmen Adaylarnın Görüsleri

\begin{tabular}{ll}
\hline 1. TEMA: Yaratıcı drama yönteminin tanımı & \\
\hline Alt Temalar & $f$ \\
G.1 Doğaçlamaya dayalı gösteri yöntemi & 11 \\
G.2 Eğitim-öğretim ortamında simülasyon & 7 \\
G.3 Aktif katılıma dayalı yöntem & 6 \\
G.4 Eğitimde kullanılan tekniklerden biri & 5 \\
G.5 Oyun Oynama, Canlandırma & 5 \\
G.6 Yaparak, yaşayarak öğrenme & 4 \\
G.7 Etkili bir iletişim & 4 \\
Toplam & 42 \\
\hline
\end{tabular}

Adayların görüşleri değerlendirildiğinde, Yaratıcı drama yöntemini farklı şekillerde tanımlandıkları görülmektedir. Adaylar yaratıcı dramayı doğaçlamaya dayalı, aktif katılımı destekleyen, oyun oynayarak öğrenme firsatı sunan, etkili iletişime izin veren, eğitim-öğretim sürecindeki önemli tekniklerden biri olarak tanımlamaktadır. Adayların yaratıcı drama tanımları şu şekilde örneklendirilebilir:

"Yaratıcı drama bireylerin tecrübelerinden hareket ederek bir konu, olay veyabut düsünceyi doğaclama yaparak

ya da rol oynama etkinliğiyle canlandirmasidır" (G3).

"Doğaçlama olan, planl ve programlı olmayan bir eğitim-ögretim yöntemidir" (G1).

\section{Yaratıcı drama yönteminin Sosyal bilgiler öğretiminde kullanılması}

Araştırmaya katılan öğretmen adaylarının yaratıcı drama yönteminin Sosyal bilgiler öğretiminde kullanılıp/kullanılmasına yönelik görüşlerinin farklılık gösterdiği tespit edilmiştir. Öğretmen adaylarını verdiği cevaplar gruplanıp alt temalar oluşturularak tablo halinde sunulmuştur.

Tablo 4. Yaratıcı Drama Yönteminin Sosyal Bilgiler Öğretiminde Kullanılmasına İlişkin Öğretmen Adaylarmın Görüsleri

2. TEMA: Yaratıcı drama yönteminin Sosyal Bilgiler öğretiminde kullanılması

\section{Alt Temalar}

Evet G.1 Kalıcı öğrenmeye katkı sağlar

G.2 Soyut konuları somutlaştırır

G.3 Derse aktif katılımı sağlar

G.4 Hayal gücünü destekler

G.5 Sosyal, duygusal gelişimi destekler

G.6 Özgüveni artırır

Hayır G.7 Müfredat program yetişmeyebilir

G.8 Sinıfkontrolündesorunyaşayabilirim

Toplam

$f$
9
7
6
5
5
3
4
3
42

Araştırmaya katılan Sosyal bilgiler öğretmen adaylarının 35’i yaratıcı dramanın Sosyal bilgiler dersinde kullanılması yönünde görüş bildirmiştir. Olumlu yönde görüş bildiren adaylar dramanın kalıc1 öğrenmeye katkı sağladığı, soyut konuları somutlaştırdığı, derste aktif katılımı sağladığ1, hayal gücünü, sosyal-duygusal gelişimi desteklediği ve özgüveni artırdığını ifade etmiştir. 7 aday yaratıcı dramanın Sosyal bilgilerde dersinde kullanılması durumunda müfredat programın yetişmeyeceğini ve yaratıcı drama etkinliğinin sınıfta kaosa sebep olacağını belirtmiştir. Öğretmen adaylarının görüşleri genel olarak değerlendirildiğinde Sosyal bilgiler dersinde yaratıcı dramanın kullanılmasına olumlu yönde baktıkları söylenebilir. Fakat 7 ögrretmen adayının ifadeleri, adaylarımızın müfredat programına sıkı bağlılığını buna ilaveten sınıf yönetimi konusunda da kendilerini yetersiz gördüklerini ortaya koymaktadır. Bu duruna ilişkin öğretmen adaylarının görüşleri şu şekilde örneklendirilebilir:

"Sosyal bilgiler dersinin içeriğinin ögrenciye, sunus yoluyla ve ögretmen merkęlli yöntemlerle verilmesi ögrenmenin kaliculiğm olumsuz etkilemektedir. Fakat drama yöntemiyle canlandinlan konular ögrencinin derse aktif

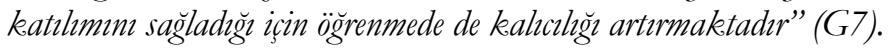


"Yaratıc drama yöntemini sınf içerisinde uygularken tüm ögrencilerin kontrolünü să̆lamada yetersiz. kalabilirim çünkü öğrencilerin tamamın sürece dabil etmek mümkün değil bu sorun sinı ortamında kaosa sebep olabilir"(G3).

\section{Yaratıcı drama yönteminin kullanılmasında öğretmen adaylarının yeterlilikleri}

Araştırmaya katılan 42 öğretmen adayının yaratıcı drama yöntemini uygulamaya yönelik yeterlilik alg1sını gösteren bulgular gruplanıp alt temalar oluşturularak tablo halinde sunulmuştur.

Tablo 5. Yaratıc Drama Yöntemi İlerde Derslerde Uygulamada Kendinizi Ne Derece Yeterli Buluyorsunuz?

\begin{tabular}{lc}
\hline 3. TEMA: Yaratıcı drama yöntemini uygulaya yönelik yeterlilik algıları & \\
\hline Alt Temalar & $f$ \\
G.1 Bu yöntemi uygulamada yeterli bilgiye sahip olduğumu düşünmüyorum & 11 \\
G.2 Drama sürecini yönetmede yetersiz olabilirim & 42 \\
Toplam & 42 \\
\hline
\end{tabular}

Adayların verdikleri yanıtlar değerlendirildiğinde, drama yönteminin derste uygulanması hususunda 31 adayın kendini yetersiz olarak ifade ettiği görülmektedir. 42 aday içerinden sadece 11 aday kendini yeterli görmektedir. Bu duruna yönelik öğretmen adaylarının görüşleri şu şekilde örneklendirilebilir:

"Kendimi yeterli bulmuyorum. Üniversitede aldı̆̆rmı eğitimin süresi çok kisa ve yetersiz. Bunun yan sira dersler genellikle teorik düzeyde kalmakta uygulamalar yetersiz. Böylesi bir durumda ileri de ögrencilerime yeterli olacağım düşünmüyorum"(G5).

"Ë̆gitim fakültelerinin ögretmen adaylarna bu konuda sunduğu imkân kısıtl. Sadece son sinfta yarm dönemlik bir ders alyyoruz. Üstelik bu dersin süresi yetersiz ve çoğunlukla ögretim üyeleri dabi bu derse gerekli önemi vermiyor "(G9).

\section{Yaratıcı Drama yönteminin uygulanması sürecinde karşılaşılabilecek problemler}

Araştırmaya katılan 42 öğretmen adayı yaratıcı drama yöntemini uygularken çeşitli problemlerle karşılaşabileceği belirtmiştir. Öğretmen adaylarını verdiği cevaplar gruplanıp alt temalar oluşturularak tablo halinde sunulmuştur.

Tablo 6. Drama Yönteminin Uygulanması Sürecinde Ne Gibi Zorluklarla Karşılaşacă̆ınz̨ Düşünüyorsunuz Ve Bu Zorlukları Cözmek İcin Ne Yapabilirsiniz??

4. TEMA: Yaratıcı Drama yönteminin uygulanması sürecindeki zorluklar

\section{Alt Temalar}

G.1Uygun araç-gereç temini. Okul idaresi ve Milli eğitim müdürlüğüyle işbirliğiyle bu sorun çözülebilir 11

G.2 Sınıf kontrolü. Meslekte tecrübe kazandıkça bu sorun çözülebilir

G.3 Sınıf kalabalıksa tüm öğrencilere görev verilemeyebilir. Gruplar halinde drama çalışması ile sorun 10 çözülebilir

G.4 Öğrencinin sürece dâhil edilmesi. Öğrenciler cesaretlendirilerek bu sorun çözülebilir

G.5. Müfredatı yetiştirmede aksaklıklar yaşanabilir. Süreci iyi planlayarak bu sorun çözülebilir

Tablo 6 incelendiğinde adayların yaratıcı drama sürecinde karşılaşabileceği sorunlara ilişkin farklı yanıtlar verdiği görülmektedir. Adaylar drama sürecinde karşılaşabileceği problemler arasında uygun araçgereç temini, sınıf kontrolü, kalabalık sınıflarda çalışma durumu, öğrencilerinin tümünün drama sürecine dahil edilememesi ve müfredat programının yetişmeme durumunu sıralamışlardır. Bu duruna ilişkin öğretmen adaylarının görüşleri şu şekilde örneklendirilebilir: 
"Özellikle disiplin sorunu olacağm ve bu sorunla öğrencilerin birbirinden kopuk, tamamen bağımsız. davranacağgn düsü̈nüyorum. Bunun yam sıra yaratıc drama yönteminde ögrenciler dikekatini asıl konuya vermeyebilir" (G14).

"Ülkemizde her okul aym imkânlara sahip değil. Göreve başlayacağım okulda drama yönteminin uygulanacağ̀ bir ortam ve arac gerec olmayabilir" (G11).

\section{Yaratıcı drama yönteminin Sosyal bilgiler dersinde uygulanması}

Araştırmaya katılan 42 öğretmen adayının meslek hayatlarına bașladıklarında yaratıcı drama yöntemini derslerinde uygulayıp/ uygulamayacaklarına ilişkin cevaplar gruplanıp alt temalar oluşturularak tablo halinde sunulmuştur.

Tablo 7. Ögrretmen Adaylarmmn Meslek Hayatlarnda Drama Yöntemini Uygulama Konusundaki Görüşleri

\begin{tabular}{lc}
\hline 5. TEMA: Görev sürecinde yaratıcı drama yönteminin Sosyal bilgiler dersinde uygulamasına \\
ilişkin görüşler & $F$ \\
\hline Alt Temalar & 9 \\
Evet G.1.Öğrenmede kalıcılığı sağlayacaktır & 9 \\
G.2.Öğrenmeyi somutlaştırma & 7 \\
G.3.Öğrencinin aktif katılımını sağlayacaktır & 5 \\
G.4. Problem çözme gücünü artırır & 4 \\
G.5.Empati becerilerini geliştirebilir disiplin sorunu yaşanabilir & 4 \\
Hayır G.6.Sınıf yönetiminde problem yaşanabilir & 4 \\
G.7.Müfredat programı yetişmeyebilir & 42 \\
Toplam & 4 \\
\hline
\end{tabular}

Adaylarımıza yöneltilen göreve başladığınızda drama yöntemini, Sosyal bilgiler dersinde uygulamayı düşünüyor musunuz? Sorusuna öğretmen adaylarımızın büyük çoğunluğunun olumlu yönde görüş bildirdiği görülmektedir. 42 adaydan sadece 8 adayın olumsuz yöne fikir belirttiği görülmektedir. Tablo 7 incelendiğinde adayların olumlu/olumsuz fikirlerini gerekçeleriyle ifade ettiği görülmektedir. Bu duruma yönelik aday görüşleri şu şekilde örneklendirilebilir.

"Kullanmayn düşünüyorum gelenelesel yöntem içerisinde yer alan düz anlatum yöntemi ve soru-cevap gibi yöntemlerle Sosyal bilgiler dersi sikıc ve verimsiz olacaktır. Ama bu yöntemle ögrencinin kesfetme gücü artacak ve konu kaluc bir şekilde ögrenebilecektir. Buna ilaveten drama yöntemi sadece ögrrenciye değgl öğretmene de pek cok katker sağlayabilir" (G4).

"Sosyal bilgiler dersinin müfredat incelendiğinde yoğun bir konu alanma sabip olduğu görülebilir. Bu sebepten ötürü konularn belirlenen zamanda bitirilmesine bu yöntem engel olabilir aym zamanda uygun ortam olamayacağm düşündüğim için kullanmayacağm”"(G1).

\section{Tartışma, Sonuç ve Öneriler}

Yaratıcı drama yönteminin etkililiğine ilişkin öğretmen adaylarının fikirlerinin belirlenmeye çalışıldığ1 araştırmada aşağıdaki bulgulara ulaşılmışır.

Çalışmada öğretmen adaylarının yaratıcı dramaya yönelik tanımlarının farklılaştı̆̆ını ve öğretmen adaylarının büyük bir kısmının yaratıcı dramayı bir olayın bir durumun ya da sorunun doğaçlaması olarak gördüğü sonucuna ulaşılmıştır. Elde edilen bulgu adayların, yaratıcı dramanın tanımına yönelik bilgiye sahip olduğunu göstermektedir.

Öğretmen adaylarının yaratıcı drama yönteminin Sosyal bilgiler dersinde kullanılmasına yönelik görüşleri incelendiğinde adayların büyük oranda olumlu bir tutuma sahip olduğu saptanmıştır. Öğrenme ortamlarının zenginleştirilmesi bağlamında bu durumun olumlu olduğu söylenebilir. Aynı zamanda ulaşılan bulgu Güven'in (2012) “İlköğretim 4. ve 5. sinıf Türkçe Derslerinde Drama Yönteminin Kullanılması Üzerine Nitel Bir Çalışma" adlı çalışmasının bulgularını da desteklemektedir. Çalışmada, drama yönteminin sınıf içi etkinlerde kullanılmasının faydalı olacağı yöntemin öğrencilerin konuları öğrenmesini kolaylaştırabileceği ve kalıcı öğrenmeye katkı sağlayabileceği bulgularına ulaşılmıştır. 
Çalışmanın bir başka bulgusu da Sosyal bilgiler öğretmen adaylarının kendilerini yaratıcı drama yöntemini uygulamada yetersiz bulduğudur. Oysaki öğretmen adayları üniversitelerde, drama dersi almaktadır. Kesici’ nin (2014) "Drama Dersine İlişkin Öğretmen Görüşleri”" adlı çalışmasında da benzer bulgular elde edilmiştir. İlgili çalışmada da, araştırmaya katılan öğretmen adaylarının önemli bir kısmı bu yöntem konusunda yeterli bir eğitim almadıklarını ve kendilerini, yetersiz hissettiklerini belirtmişlerdir. Bu durum üniversitedeki drama dersi ile öğretim ilke ve yöntemleri dersinin süresi ve veriminin artırlması mecburiyetini de beraberinde getirmektedir.

Yaratıcı drama yönteminin uygulanması sürecinde karşılaşlabilecek problemler hususunda ise adaylarımız farklı yanıtlar vermişlerdir. Öğretmen adaylarının önemli bir kısmı sınıf kontrolünü sağlamada ve araç gereç temini konusunda zorluklar yaşayacağını belirtmişlerdir. Başçı ve Gündoğdu'nun (2011)“Öğretmen Adaylarının Drama Yöntemine İlişkin Tutumları ve Görüşleri: Atatürk Üniversitesi Örneği” adlı araştırmasında da, çalısmaya katılan öğretmen adaylarımız ilgili çalışmamıza katılan öğretmen adaylarımızla özleşen fikirlere sahiptir. Nitekim Başcı ve Gündoğdu'nun çalışmasına katılan öğretmen adaylarının ilgili yönteme ilişkin örneklendirilmiş görüşünü incelendiğimizde "Drama smmfinın olmaması etkinliklerimiz̨i olumsuz etkiledi. Kostümlerde araş ve gereçlerde yetersiz̨likler vardi" şeklindeki ifadesi bu sonucu destekler niteliktedir.

Çalışma grubumuzu oluşturan öğretmen adaylarımız mesleki hayatlarına başladıklarında drama yöntemini, Sosyal bilgiler dersinde uygulamayı/ uygulamayacağına yönelik soruya çeşitli cevaplar vermiştir.42 öğretmen adayımızın 34’i bu yöntemi meslek hayatlarında kullanacağını belirtirken 8 öğretmen adayı ise, kullanmayacağını belirtmiştir. Oğuz ve Beldağ’ın (2015) "Sosyal Bilgiler Dersinde Yaratıcı Drama Yönteminin Kullanılmasına İlişkin Öğretmen Adaylarının Görüşleri” adlı çalışmasının bulguları incelendiğinde çalışmamızın bulguları ile örtüşen sonuçlar görülebilmektedir. Mevcut çalıssmada da öğretmen adaylarının büyük kısmı bu yöntemi kullanmak istediklerini vurgulanmış fakat bir kısım öğretmen adayı ise bu yöntemin bir takım zorlukları olduğuna vurgu yaparak, kullanılması sürecinde bazı güçlüklerle karşılaşacağını ifade etmiştir.

Öğretmen adaylarının vermiş oldukları cevaplar dikkate alınarak yaratıcı drama yönteminin etkililiğine ilişkin şu önerilerde bulunulabilir:

- Yaratıcı drama yöntemi sınıf ortamını zenginleştiren, öğrenci merkezli bir yöntemdir. Yapılandırmacilığa dayalı olarak hazırlanan Sosyal bilgiler ders programlarında diğer yöntem ve tekniklerin yanı sıra bu yönteme de daha sık yer verilmelidir.

- Öğretmen adaylarımızın büyük çoğunluğunun yaratıcı drama yöntemi hususunda kendini yetersiz bulduğunu ifade etmesi göz önünde bulundurulduğunda, üniversitelerin eğitim fakültelerinde ögretmen adaylarına verilen drama dersi ile öğretim ilke ve yöntemleri dersinin önemi daha iyi anlaşılmaktadır. Bu hususta ise, öğretmen adaylarına verilen ilgili derslerin iyileştirilmesi, zenginleştirilmesi ve uygulamaya ağırlık verilmesi faydalı olabilir.

- Öğretmen adaylarının sınıf kontrolünü sağlamada kendini yetersiz gördüğü anlaşılmıştır. Bu hususta okul deneyimi ve öğretmenlik uygulaması süreci gözden geçirilerek aksaklıklar giderilmeye çalışılmalıdır.

Öğretmen adaylarının müfredat programına sık1 bir bağlllı̆̆1 görülmektedir. Elbette belirlenen hedefler doğrultusunda kazandırılacak kazanımlar vardır. Fakat tüm kazanımların öğrenciye harfiyen aktarılmasından ziyade öğrencide yaşantı değişikliği oluşturacak şekilde verilmesinin önemli olduğu bilinci öğretmen adaylarına kazandırmalıdır.

\section{Etik Beyan}

“Sosyal Bilgiler Öğretmen Adaylarının Yaratıcı Dramanın Bir Öğretim Yöntemi Olarak Kullanımına İlişkin Görüşleri” başlıklı çalışmanın yazım sürecinde bilimsel, etik ve alıntı kurallarına uyulmuş; toplanan veriler üzerinde herhangi bir tahrifat yapılmamış ve bu çalışma herhangi başka bir akademik yayın ortamına değerlendirme için gönderilmemiştii. 


\section{Kaynakça}

Adıgüzel, Ö. (2015). Eğitimde yaratıcı drama (6. Baskı). Ankara: Pegem Akademi Yayınevi.

Aykaç, M. ve Adıgüzel, Ö. (2011). Sosyal bilgiler dersinde yaratıcı dramanın yöntem olarak kullanılmasının öğrenci başarısına etkisi. Kastamonu Eğitim Dergisi, 19(1), 297-314.

Aykaç, M. ve Çetinkaya, G. (2013). Yaratıcı drama etkinliklerinin türkçe öğretmen adaylarının konuşma becerilerine etkisi. Turkish Studies, 8(9), 671-682.

Bilgili, A. S. (2006). Geçmişten günümüze sosyal bilimler ve sosyal bilgiler. İçinde İ. H. Demircioğlu (Edt.). Sosyal bilgilerin temelleri (ss. 3-56.). Ankara: Pegem Yayınları.

Başçı, Z. ve Gündoğdu K. (2011). Öğretmen adaylarının drama dersine ilişkin tutumları ve görüşleri: Atatürk üniversitesi örneği. Elementary Education Online, 10(2), 454-467.

Büyükköztürk, Ş., Çakmak, E. K., Akgün, Ö. E., Karadeniz, Ş. ve Demirel, F. (2008). Bilimsel araștırma yöntemleri. Ankara: Pegem A Yayıncilık.

Chen, C. (2003). A constructivist approach to teaching; implications in teaching computer networking. information technology. Learning and Performance Journal, 21(2), 17-27.

Dirim, A. (1998). Okul öncesi eğitiminde yaratıc drama.İstanbul: Esin Yayınları.

Gönen, M ve Dalkılıç, N. U. (2000). Cocuk eğitiminde drama yöntem ve uygulamalar.İstanbul: Epsilon Yayıncıllk.

Güven. A. Z. (2012). İlköğretim 4. ve 5. sinıf türkçe derslerinde drama yönteminin kullanılması üzerine nitel bir çalışma.Cumburiyet International Journal of Education, 1(2), 58.

Kara, Y. ve Çam, F. (2007). Yaratıcı drama yönteminin bazı sosyal becerilerin kazandırılmasına etkisi. Hacettepe Üniversitesi Ë̆itim Fakültesi Dergisi, 32, 145-155

Karadağ, E. ve Çalışkan, N. (2008). Kuramdan-uygulamaya ilkëğretimde drama. Ankara: Arı Yayıncılık.

Koçoğlu, E. (2017). Kültürel değerlerle sosyal bilgiler eğitimi. İçinde R. Sever, M. Aydın ve E. Koçoğlu (Edt.). Alternatifyaklaşımlarla sosyal bilgiler ögretimi. Ankara: Pegem Akademi.

Oğuz, A. ve Beldağ A. (2015). Sosyal bilgiler dersinde yaratıcı drama yönteminin kullanılmasına ilişkin öğretmen adaylarının görüşleri. Turkish Studies, 10(15), 667-680.

Ömeroğlu, E., Ersoy, Ö., Şahin, F. T., Kandır, A. ve Turla, A. (2003). Okul öncesi eğitimde drama teoriden uygulamaya. Ankara: Kök Yayıncılık.

San, İ. (1996). Yaratıcılığı geliştiren bir yöntem ve yaratıcı bireyi yetiştirme bir disiplin: Eğitsel yaratıcı drama.Yeni Türkiye Dergisi, 7,148-160.

Şimşek, S.(2009). Eğitimle ilgili temel kavramlar. Eğitim bilimine giriş (Edt: N. Saylan) (3. Baskı). Ankara: Anı Yayincilik.

Tanrıseven, I. ve Aykaç, M. (2014). Üniversite öğrencilerine zamanı iyi kullanma farkındalığının yaratıcı drama yoluyla kazandırılmasi. Pamukkale Üniversitesi Ë̈itim Fakültesi Dergisi, 36(2), 87-100.

Üstündağ, T. (1996). Yaratıcı dramanın üç boyutu. Yaşadıkça eğitim, Eræ̌incan Üniversitesi Eğitim Fakültesi Dergisi, 6(1), ss.19-23.

Üstündağ, T. (1998). Yaratıcı drama eğitim programının öğeleri. Eğitim ve Bilim Dergisi, 22(107), 28-35.

Yıldırım, A. ve Şimşek, H. (2005). Sosyal bilimlerde nitel araştırma yöntemleri. Ankara: SeçkinYayıncılık.

\section{EXTENDED ABSTRACT}

The changes experienced by countries in the technological, economic and political fields have also changed the needs and perspectives for education. The countries of the world aim to educate individuals who have a critical point of view that are autonomous and problem-Oriented. Until the 1950s, the behavioural approach that was the basis of educational understanding was insufficient to meet the needs of countries. The behaviorist approach advocates a specific understanding of education that borders on teacher-controlled, ignoring student interests and needs. This has led the behaviorist approach to be replaced by the constructivist learning approach, which is an approach that cares about the interests and wishes of the learners and which bases the experiences of the learners on solving the problem. In this approach, it is important to have knowledge and to use it effectively rather than having it. Another characteristic of constructivist learning approach is that each student is a different individual. Such an understanding has brought about the understanding that learning processes will differ from individual to individual. In this case, the teacher is expected to use contemporary teaching methods and techniques that will enrich the teaching-learning process and make every learner active in the learning process. One of these contemporary methods is the creative drama method. Creative drama is the portrayal of individuals in a subject, event or life through activities such as improvisation and theatre (San, 2002). This method allows individuals to recognize themselves, empathize and be prepared for on months they have not experienced before. During creative drama studies, learners are able to realize their own limits and gain self-confidence that they can solve potential problems in life. It is thought that there will be advantages for primary school children to be introduced to the creative drama method. During this period, creative drama can help children who transition from the concrete process period to the abstract 
process period to embody abstract concepts, understand lesson topics more easily and analyze and evaluate current events. However, creative drama increases the individual's communication ability, social skills and can contribute to socialization. The use of creative drama, especially in courses where verbal learning is weighted, increases the level of recollection of the subjects learned and can contribute to the increase of the academic success of the students. Social studies are one of the main courses of verbal learning, so it is thought that the use of creative drama method will be useful in this course.

Social studies course has been revised in the framework of constructivist learning approach since 2004-2005. In this context, it has become necessary to use methods and techniques such as problem solving, creative drama, sightseeing, observation, experimentation, six-hatted thinking technique, brainstorming, vision development that will keep students ' curiosity constantly high and contribute to their active learning. However, in a social studies study, teachers used methods such as question and answer (219), expression (152), visual material reading (132), creative drama, brainstorming, vision development, etc. methods and techniques have been found not to be used adequately. This shows that social studies courses cannot be saved from traditional understanding (Aykaç and Adigüzel, 2011, 299). The aim of this study is to determine the ideas of social studies teacher candidates for the use of creative drama method. The ideas of the teacher candidates for this course, which is important for the learners, are important. Because the practitioner of this method in the classroom is the teacher. Interview technique from qualitative research methods was used in the study. When determining the relevant working group of the research, situated inside purposive sampling methods, criterion sampling method was used in the context of this research at a State University in the academic year 2016-2017 data in the eastern region, Faculty of Education, Department of Turkish and social sciences education, studying in the Department of Social Sciences of 4 . the class was collected from 42 teacher candidates. The interview form developed by the researcher was used as the data sum tool. [Reliability $=$ Consensus / (Consensus + difference of opinion)] was used in the reliability formula proposed by Miles and Huberman (1994) for the reliability calculation of the questions in the interview form consisting of 5 questions. Content analysis and descriptive analysis techniques were used to analyze the data.

Overall findings from the research show that teacher candidates define creative drama in different ways. The majority of prospective teachers have defined creative drama as an improvised method of demonstration. When other definitions of creative drama were examined, definitions such as supporting active participation, offering the opportunity to learn by playing games, allowing effective communication, and one of the important techniques in education were determined. Other findings from the study are that prospective teachers have a positive attitude towards the use of creative drama in Social Studies. 35 out of 42 teacher candidates stated that creative drama method should be used in social studies class, while 7 teacher candidates reported negative ideas. Another data obtained from the interview with the teaching candidates is that the education they received in the creative drama method is not sufficient. The candidates for teaching have expressed the opinion that I find myself inadequate in the method and application of creative drama. At the same time, teacher candidates have stated that they may encounter various problems when applying the drama method in their professional lives. The problems that candidates may face in the creative drama process include the provision of appropriate equipment, class control, working in crowded classrooms, the inability to include all of their students in the drama process and the lack of curriculum. The latest findings of the study show that the vast majority of teacher candidates want to use this method when they start their professional lives. 34 of our 42 teacher candidates stated that they would use this method in their professional lives, while 8 teacher candidates stated that they would not. 